\title{
The Limits of Hegemony?
}

\author{
L’uboš Blaha $^{1}$ \\ Katedra politológie a európskych štúdií, Fakulta sociálnych vied UCM, Trnava
}

The Limits of Hegemony? In this study I will try to put forward the views of the social theorists and critics who consider "postmodern culture" (Jameson) as deeply manipulative. The fundamental patterns of the system of the ideology preach to the spread of the values of consumerism, individualism and hedonism (Fromm). As the study shows, the media play a key role in spreading these values (Chomsky). The media became the main "ideological apparatus" (Althusser) and the business world, the world of culture and politics is controlled by these media. Economic system thus gains support of the population and can reproduce itself. According to some interpretations there is no escape from the environment of the systemic manipulation (Jameson, Foucault, Marcuse), but there are also opinions according to which systemic indoctrination can intervene only in the public - official discourse, but not culture and behavior patterns of marginalized groups (Scott, Bloch, Williams). I will try to interpret and analyze systematically these two intuitive views. In this context, I will develop the thesis that the value of truth, not as an epistemologically or metaphysically regulative principle, but as a socio-emancipating force which can have in the environment of the absolute manipulation a decisive impact in the formulation of alternative to the current (post)modern global-capitalist society. The study is based on the author's book Matrix of Capitalism: Is the Revolution Coming? (Veda, Bratislava 2011).

Key words: media, manipulation, Noam Chomsky, indoctrination, propaganda

Hranice hegemónie? V štúdii sa pokúsime predostriet' názory sociálnych teoretikov a kritikov, ktorí „postmodernú kultúru“(Jameson) považujú za hlboko manipulačnú. Základné vzorce systémovej ideológie kážu, aby sa $v$ spoločnosti šírili hodnoty konzumu, individualizmu a hedonizmu (Fromm). Ako štúdia ukazuje, médiá v šírení týchto hodnôt zohrávajú klúčovú úlohu (Chomsky). Stali sa totiž hlavným „ideologickým aparátom"(Althusser) a ich prostredníctvom je ovládaný svet biznisu, kultúry aj politiky. Ekonomický systém takto získava podporu obyvatel'stva a môže sa d'alej reprodukovat'. Podl'a určitých interpretácií z prostredia systémovej manipulácie niet úniku (Jameson, Foucault, Marcuse), no existujú aj názory, podla ktorých systémová indoktrinácia dokáže zasiahnut' iba verejný, oficiálny diskurz, no nie kultúru a vzorce správania sa marginalizovaných skupín (Scott, Bloch, Williams). Pokúsime sa tieto dva intuitívne pohl'ady systematicky interpretovat' a analyzovat'. V tejto súvislosti rozvinieme tézu, že hodnota pravdy, nie ako epistemologický či metafyzický regulatív, ale ako sociálnoemancipačná sila, môže mat' $\vee$ prostredí totálnej manipulácie rozhodujúci vplyv pri formulovaní alternatívy voči súčasnej (post)modernej globálno-kapitalistickej spoločnosti. Štúdia je postavená na autorovej knižke Matrix kapitalizmu - bliži sa revolúcia? (Veda, Bratislava 2011).

Klúčové slová: médiá, manipulácia, Noam Chomsky, indoktrinácia, propaganda

\footnotetext{
${ }^{1}$ Address: PhDr. L'uboš Blaha, PhD., Katedra politológie a európskych štúdií, Fakulta sociálnych vied, Univerzita sv. Cyrila a Metoda v Trnave, Bučianska 4/A, 91701 Trnava, Slovenská republika. E-mail: lubos.blaha@ucm.sk
} 
In my paper I would like to focus on the criticisms of Western society which was offered by the classics of critical theory as Herbert Marcuse and Erich Fromm. They present the modern capitalist society as totalitarian and deeply rigged one. The basic formulas of system ideology are preaching the spread of the values of consumerism, individualism and hedonism (Fromm). The economic system obtains the support from population in this way and can reproduce itself.

In the first chapter we will introduce the theory of a well-known American intellectual, Noam Chomsky. We will try to concentrate on the issue of media manipulation in modern societies. In the next chapters we will more closely develop the thesis that today's system works through the manipulation of people and we will try to substantiate this thesis by the theories of philosophers like Louis Althusser, Herbert Marcuse, Ernst Bloch and Fredric Jameson.

The paper will be framed by the particular search for an answer to the question whether there is an escape route from the system of cultural and media manipulation. According to some interpretations there is no escape from the environment system manipulation (Jameson, Foucault, Marcuse) but there are also some opinions arguing that the system of indoctrination can intervene only in the public, official discourse, but not in culture and behavior patterns of marginalized groups (Scott, Bloch, Williams). I will try to systematically analyze and interpret these two intuitive insights.

In this context, I will develop the thesis that the value of truth is not as an epistemological or metaphysical regulative, but as a socio-emancipating force, that may have a decisive influence in the formulation of alternatives to the current (post) modern global-capitalist society in the environment of total manipulation and cultural hegemony.

\section{Media and manipulation: The Critique of Indoctrination by Noam Chomsky}

The information absorbed by people around the world every day shapes their world view and defines their aspirations, dreams, desires and identities. Large capitalist corporations have completely dominated the world of information and with few exceptions we can speak about a monopoly of capitalist thinking in the media sphere. People are therefore confronted every day with this kind of information which is selected and imposed to them by the ruling forces of economic liberalism. Therefore critical thinking by people is not and cannot be developed because people are not confronted with the facts about the monstrosity of contemporary capitalism, but on the contrary, they live under the illusion which is created by the "business-friendly" propaganda.

And, in this manner, the modern society is presented by the American philosopher and linguist Noam Chomsky, one of the greatest living "public 
intellectuals" nowadays. In his politico-philosophical reflections he gives a comprehensive critique of capitalist indoctrination and manipulation by the media. In his reflections he is trying to show that we do not live our own real lives. We are experiencing exactly the same lives which the capitalist system wants us to live. And also we do not have our own values. We passively accept those values which the modern market society wants us to accept. We are creatures of capitalism - the outlets for its products and devoted consumers of its frequently perverse thoughts... Capitalism appears as if it created its own "matrix" in which the people are held in a deep illusion. And we are all sleeping. It is a sweet sleep of the manipulated and the deceived...

All major corporate mass media keep people in deep passivity and dogmatize the basic "truth", which are suitable for maintaining the system. Outwardly, it may seem that the current liberal mass media are sufficiently critical, because, after all, they provide a persistent or even a radical critique of society. This gives us the impression that the social system is sufficiently criticized and someone is constantly working on improving it. The media are presented as tireless defenders of truth, justice and critical attitude. There is an idea that anything that can be criticized will certainly be criticized in the media. This is how a framework for criticism is being made and it is impossible to step out of it. The system is fortified by this invisible barrier and the media, limited in their critical capacity, have to create the illusion that it is sufficiently open and free. Precisely in this direction we can decrypt Chomsky's criticism of the media, which will be illustrated in this chapter.

As Chomsky points out, the basic fact from which media's action unfolds is based on its economic substance. As he writes: "[The i]nformation system, at least in economic terms, is basically a system of corporations that are trying to sell their product to a relatively privileged and influential listening elite, i. e. other corporations" (Chomsky 2001: 25). The major media are large corporations, owned by - and interlinked with - even larger conglomerates. Like other corporations, they sell their product in a market. Their primary market is not the public but advertisers, i. e. other corporations. Their product is their viewership, respectively the audience. It is therefore of no wonder that the picture of the world offered by the media represents their narrow interests as much as the values of the owners of those media and the subscribers of their advertising services (Chomsky 1994a: 93).

If the media wanted to defy conformity with a coincidence promoting the interests of the privileged strata which feed them by commercials, they would immediately be warned that the influx of cash flows would quickly fall down and that they might not survive in the market. The case that the media would want to stand up is purely hypothetical because this option is ruled out in principle. Top management in the media is drawn from the ranks of wealthy 
professionals who naturally tend to share the view of the powerful and the privileged, not to mention that they have achieved their position by having demonstrated their loyalty and efficiency with which they were serving the needs of the dominant elites (Chomsky 1987: 125; cf. Chomsky 1992: 67-68). In this relation, we should recall the idea of a Marxist sociologist, Ralph Miliband, who argues in this context that the capitalists, state bureaucrats, political leaders, as well as ideological workers are squeezed into one cohesive group by the same social origin, similar lifestyle, values and the existence of frequent networks and forums in which the coordinated strategies of state policies are developed. And thus in such an ideological apparatus, the vast majority of cases are people from social classes which can reliably be expected to assume pro-capitalist views on the issues of the economy and the industry (Svensson 1995).

The media themselves are owned by economic elites and it is out of question that the owners and managers would not keep an eye on their workplace (Chomsky 1992: 139). Another Neo-Marxist, Richard Miller eloquently writes: "If politicians are not literally owned by the bourgeoisie, the mass media typically are" (Miller 1984: 110). The basic reason for their way of informing the public is therefore quite prosaic - they serve the interests of their owners. As Chomsky illustrates: "The hegemony of the corporations in the media works in a systematic, structural manner and the selection of the news and information accessible to the broad public rests with them. The result is not achieved by confidential agreements made in smoke-filled rooms but it simply emerges from the fact that many of those who make decisions independently of each other work within the same worldview, the same values and they follow the same goal- to get profit for their own holding companies. Media controlled by corporations behave more like a flock of fish (or sharks perhaps) that is able to dodge in unison even without plans to coordinate their behavior. The smell of blood and the perception of the corporation needs, which feed them, suffice (...) TV stations breed auto-censorship to benefit from commercials and they weed out that bunch of journalists who resolve to criticize the system" (Winston 2004: 100). An idea actually not unlike the one of Miliband.

As we can summarize, the fundamental reasons of the manipulating function by the media can be divided into two main areas:

\section{Ideological (Systemic) Reasons}

As Chomsky says, when people in the modern democratic society got the basic political and civil rights, the difficulty to control them by force and physical coercion increased. In a state based on internal violence and repression, it suffices to control what people do and it does not matter so much what they think. However, if state violence becomes limited, it is necessary to control 
what people think (Chomsky 1987: 127; cf. Chomsky 1988: 256). Therefore, it has become a necessity for the preservation of the system to grab people's thinking, to isolate them and undermine popular resistance and its organizations (e. g. trade unions or unsystematic political parties), which would help ordinary people to intervene meaningfully in the political arena. The means to control their thinking have over time reached an extraordinary degree of highly organized manipulation of class consciousness by the means of "control of the public mind". To ensure stability, the elite elements of the society were indoctrinated with proper beliefs and the rabble has been marginalized and subjected to manipulating illusions. The media became the optimal means for such action (Chomsky 1993b: 12; cf. Chomsky 1988: 2-3). Chomsky does not defy the functionalist argumentation where in this respect he claims that "no institution is going to happily design a self-destruct mechanism. It's not the way institutions function. So they'll work to exclude or marginalize or eliminate dissenting voices or alternative perspectives and so on, because they are dysfunctional, they are dysfunctional to the institution itself" (Chomsky 1999: 5).

\section{Practical (Economic and Political) reasons}

The media owned by large corporations naturally hold pro-capitalist views and represent the interests of their owners and their customers of advertising services. It is not necessary to force them to their manipulating function because it is based on the rational action of the owners and managers of these corporations. Only a short psychological reasoning would suffice - why would these market owners, for whom the market society and the status quo are very convenient, have an interest in the mass media which they own, look at the often absurd nature of the social system in which we live? The same goes for the state. Its interest is to maintain the media in a moderate level of criticism, however, the criticism of the substance of the system is absolutely excluded. After all, if such a criticism by the mass media was released, the regime itself would be suddenly in danger and the media would simply cease to fulfill their social function. This common feature is that they keep repudiation of certain truths, convenient for the state, big businessmen and others who benefit from the social organization. The logic of functionalism cannot be avoided. The media have a clear function in the system, although they often want to mask it by the effort of creating an image of "watchdogs" of democracy. Watchdogs do not bite their masters - their role is to guard the system, not democracy necessarily.

In carrying out their system mission the mass media carry out more specific functions and tasks. Chomsky describes some of them in his reflections. In principle, they can be divided into three distinct areas: 


\section{A Constructive function}

As Chomsky says, the media generally focus on ensuring "right thinking" or, more precisely, a thinking that is in favor of maintaining the system (Chomsky 1993c: 125). This is a constructive part of the indoctrination, and thus the creation of ideological constructs, bringing value patterns with special purpose and socialization in favor of the ruling elites.

\section{B Destructive function}

This category may include media attacks on thinking which stands outside of the system. This is a demonization of dangerous components (e. g. unions, radical left-wing political parties or alter-globalists), marginalization and belittlement of alternative thinking (e. g. ecologists and feminists), ridicule and degradation of unwanted institutions (e. g. the welfare state, progressive taxation etc.) and dishonor or discredit those people who stand cross-current (e. g. unwanted politicians from anti-American countries) and so on (Chomsky 1996: 118, 138-139).

\section{Inhibitory function}

The final category we can find in the "dampening" function of the media which aims to create an atomized mass of consumers indifferent to political problems. The media thus dampen a potential political activity and involvement of people. Horkeheimer and Adorno wrote that "modern communications media have an insulating effect..." (Horkheimer - Adorno 1972: 221). As Chomsky writes: "Much better to create a world in which people behave individually and the powerful win. The goal is a society in which the basic social unit is you and your television set. If the kid next door is hungry, it's not your problem. If the retired couple next door invested their assets badly and are now starving, that's not your problem either" (Chomsky 2001: 41). The aim is to create social apathy, narrow mindedness of the individuals, political indifference and consumerist hedonism. The task is to create a docile and indifferent citizen who is also an active and splurging consumer.

Chomsky focuses mostly on techniques or, to be more precise, on tactics of media manipulation. In principle, he notices that the media propaganda is focused on two different objects and therefore there are two components of indoctrination. The first serves for manipulating the intelligence and educated people, the other simply stupefies ordinary people.

We can divide media outlets into two categories on the basis of objects of propaganda:

\section{Manipulation of Intelligentsia}

We can include the elite political mass media into this category. Their aim is to fully indoctrinate those sections of society that are capable of some critical 
thinking. The group of these people which, according to Chomsky consists of roughly $20 \%$ of the society, is confined to basic social axioms that help maintain the system's integrity. This process occurs in different ways. Chomsky talks about choosing topics, sorting events, highlighting, misleading the context, filtering information, keeping the discussion within certain limits, etc. "They determine, they select, they shape, they control, they restrict - in order to serve the interests of the dominant, elite groups in the society", says Chomsky (1999: 4; cf. Chomsky 1994: 94).

The consequence is alarming: as Chomsky says, "you find a good deal more sophistication among people who learn about the world from their experience rather than those who learn about the world from a doctrinal framework to which they are exposed to and that they are expected - as a part of professional obligation - to propagate" (Chomsky 2001: 22). They are therefore just intellectuals, politicians, journalists and public figures who are exposed to the most powerful strain of indoctrination and they represent the best manipulated objects of the system. The reasons are various. One is prosaic - the better educated people read more and they are interested in political debates. On that account the direct political indoctrination has a stronger impact on them. At the same time being easy to be manipulated is related to their social status. Mainly it is the privileged elites who share the interests of the ruling classes (Chomsky 1992: 65).

In principle, we can divide the manipulation of the policy-oriented news and commentary intelligentsia into different techniques used by direct and indirect methods:

\section{a) Direct Methods}

Among the direct methods we can find the practices of media which strongly distort the legacy of non-conformist political subjects, whether by misrepresentation, falsification, cutting or feeding with false information. The Direct Method is also the ignorance of inconvenient political views or their purposeful ridicule or violation. Chomsky's words: "One would be hard put to find even a mild democratic socialist in the mass media, and a genuine opposition press is difficult to imagine" (Chomsky 1987: 126). The Direct Method becomes the marginalization and trivialization of alternatives or offering of inadequate space for unconventional views. The common denominator is a kind of symbolic violence, or rather, media repression.

Chomsky describes the particular time limits very broadly as they de facto liquidate the opportunity for expressing non-conforming ideas. As Chomsky writes about his personal experience: "During the two minutes between commercials or when a specified number of words you can say only a few conventional matters. Let's say for example that they gave me two minutes on 
the radio to condemn Russian invasion of Afghanistan ... It is easy, I don't have to back it up with any evidence, I do not need facts, I can say anything, I can get away with anything, because it corresponds to conventional thinking, that's what everyone is still convinced about, and so when I say this, there is nothing surprising, I do not have to prove it. But let's say that I wanted to condemn the U.S. invasion of South Vietnam or U.S. attack against Nicaragua in two minutes. It sounds crazy. The United States does not attack other countries! In two minutes between the commercials it will sound absurd. And the reason is that if you say something unconventional, it is expected - naturally and rightly that you give some evidence that you provide arguments why you have such an unconventional view. The entire structure of the American media, however, prevents it and makes it impossible. Then the consequence is that only the conventional view can be expressed, the conventional doctrine. It is a very effective technique to prevent the expression of any independent thinking and criticism" (Chomsky 2001: 23; cf. Chomsky 1993c: 138-139).

To sum up, three basic methods of direct manipulation can thus be divided as follows:

- Distortion

- Marginalization

- Limitation

\section{b) Indirect Methods}

Among the indirect methods variety of techniques that operate essentially nonpunitive may be included. In this case the media directly do not false, or misrepresent, and do not limit or refuse access to alternative non-systematic views, but they still perform the manipulating function by sophisticated methods. In particular, three methods that can be defined as:

- Apriorism

- Framing

- Doublespeak

As Chomsky claims, one of the most effective ways of manipulation is to devise stimulating debates and critical controversies under the system of unspoken presuppositions that incorporate awareness to the basic principles of the doctrinal system. These principles are excluded from criticism and inspection, and they become a skeleton and framework of the thinkable, they are not objects of rational consideration. The more the debate rages within the permissible bounds and defined system borderlines, the more efficiently the unquestioned premises that are instilled behind these debates as a kind of sacred Truths (Chomsky 1987: 127).

The basic principle standing behind this apriori tactics is that the doctrinal dogma should not be and are not directly articulated. They do not become the 
subject of reflection, they are only suggested implicitly. They get so into people's minds without being subjected to any alternative critical assumption (Chomsky 1993c: 29). These are sacred truths that are undeniable and they cannot be exposed even to the slightest intellectual challenge. Discussions repeated every day with silently adopted axioms thus become a perverse ground for any controversy. Owing to them ideology is constantly moving latently in any environment of debate and speaker cannot move in a given doctrinal logic. The doctrine is so entrenched in the minds of the public as a necessary basis for a framework for any discussion (Chomsky 1988: 118-119).

The second method is to form certain spatial boundaries, within which criticism cannot stand up. This is linked with the mentioned dogmas of ideology but also with the overall focus of criticism which always moves only within the system and thus sanctifies it. If the media offer any semblance of strong and uncompromising criticism of existing institutions their role is to work within a limited framework and independent thinking and aggressive criticism becomes only the trivial system product (Chomsky 1992: 11). The role of the media is to create the public impression that they go to the core of problems which, however, always remains only the surface. Framing of the media outlets into the system boundaries does not allow alternative thinking to express complex systemic challenge of the ideology. As Chomsky puts it: "It is necessary to create a framework of possible thinking limited by the rules of state ideology. These do not need to be enforced, it is more reasonable to expect them as an inexplicit framework of a thinkable thinking. Critics maintain this system in a way of silent acceptance of these doctrines and they limit criticism to tactical questions emerging in this framework.... Orwell did not realize this system of thought control and dictators never comprehended it either. It did not even occur to them how useful is the indoctrination and agreement with mass of critics who condemn mistakes and failures of management but they silently accept basic fundamental ideas of the state ideology" (Chomsky in Winston 2004: 98).

When a representative of unconventional thinking offered any evidence about his or her truth in the media, the media mocked him beforehand only by applying apriorism and framing. However, it is essential that it generated the impression that news and political debates are balanced, neutral and impartial. However, there is no measure of balance, according to Chomsky. Not even within the given system and ideology. According to him, it would be even fair if the media honestly and directly told to whose interests they serve, in which ideology they move and what a priori assumptions they hold. But it cannot be so because the illusion of objectivity and balance are their main propaganda weapons. If the media can be thought of as a critical and antagonistic power, and if it is possible to write that they are the "watch dogs of democracy" their 
persuasive ability and indoctrination potential are much higher (Chomsky 1994b: 151-154).

The last indicated an indirect way of manipulating is the use of Orwellian doublespeak (the language of propaganda and ideology distorting actual meanings of words). As Chomsky notes, in the news, especially on the television, we hear various hackneyed phrases defining the range of "acceptable views abounding in emotional acting simplifications been said mechanically in a seven minute interval between commercials (Winston 2004: 98). Emotional simplifications and semantically distorted words, the use of which we already described in the section on the ideological apparatuses, one of the standard methods of transferring conventional opinion to public.

\section{Diversion, or rather, dumbing down the ordinary people}

The second category of propaganda aims at an endless dumbing down of the population. Its main task is to distract ordinary people from the real problems and, vice versa "to get them to watch National Football League and to be interested about a mother of a child with six heads, or anything else what they will throw them" (Chomsky 1999: 5). How Chomsky notes, as we have just quoted, the most important thing is to reduce people's ability to think and thus relegate them to the edge of political influence. Such people will be fully subjected to populism, propaganda and indoctrination.

This is related to the functional movement of political news from the popular media to the elite political media. In popular media, political news get even a smaller space or it is being narrowed to the news of tabloid character. This, according to Chomsky, makes sense because the primary objective is to destroy authentic democracy, and thus defer ordinary people from the political sphere. So the more soap operas and sitcoms can glimpse into the television, the fewer news services and political debates, the better it is for the system. Some political news services certainly must let go - people need to know, at least in an abridged manner, what is going on in politics. Their interest, however, should remain in the field of statistical plane (Chomsky 1996: 147). The role of ordinary people is that of not caring, and the media give them optimal space for a fulfillment of this role. Without the need to venture into considerations of fairness in the political system, the viewers, listeners and readers are inundated with information and the tabloid cult of personalities from show business. How Horkeheimer and Adorno point out, film stars become the experts for ordinary people in modern society, their performances are role models and guides of natural behavior (Horkheimer - Adorno 1972: 252).

Today, according to Chomsky, "pseudoinformation" is broadcasted, seeking to encourage mass consumption of films, fashion, cosmetics, luxury holidays, 
everything is now on sale, further grow the "cult of celebrity" identical in substance with hyperconsumerism lifestyles of the rich and famous people. This variety of "soft news" is crammed into the seven minute gaps between commercials because those are in fact the reason for broadcasting. According to Chomsky, the objective of the media is to soothe ignorant masses in a state of political apathy. They achieve it by pleasant distractions - consumerist fantasies, interests of soulless professional sport and grossly simplified and variations of distorted events - thus grow "philosophy of futility" and lack of purpose in life, focusing on things superficially forming a significant part of fashion consumerism.

The mission of the media to dumb down ordinary people makes them the privileged guardians against the threat of public understanding and engagement. They create a nationwide environment of distractions; they divert excess interest from the masses decisions which are plotted for them. Whenever social consciousness exceeds these limits, it can be assured that the established media will distort and disguise the reasons for protest, as it happened in the case of large-scale alter-globalist demonstrations during the World Trade Organization meeting in Seattle in November 1999. The established press labeled protesters as losers and duffers acting up against existing globalization and "free trade". The TV only focused on several vandals breaking shop windows. This way the TV commented on that event in favour of demonization of alternative thinking. I... If someone wanted to make a more accurate view of what actually happened in Seattle and why it had to turn to socalled alternative press (Winston 2004: 101-102). The question is how many people actually did so?

\section{System Covering Maneuvers?}

According to Chomsky's critics, in his attack on the media he ignores the fact that political news and write-ups are not formed by media owners but by individual journalists who are free in their activities. Their professional honor to command them in order not to cooperate with the authorities and to be their imploring critics. They have the right to disagree and criticize, and this is also used frequently.

However, Chomsky opposed that, in fact, journalists do not have such freedom. Journalists and commentators have two options: either to adapt or to be excluded. Those who adapt and remain in the system will soon internalize the beliefs and attitudes which they are to express in their daily work and shape the course of their work. It is difficult to imagine a man who says something but thinks something else, especially if it should be part of his daily life. Therefore, most journalists prefer to adapt and adopt the values of the system itself. Finally, some space for criticism of the system is allowed. In the shared 
consensus of the systems minor problems and narrow tactical questions can be critically reflected. The institutional structure of the system and its essence, however, turns hostile to independent thinking. If such a journalist with an independent view would be found, then sanctions by the system follow. Such a person is not locked up in jail or persecuted. Penalties of the system operate in a different manner, so that such a journalist will not find a job in the corporate media system anymore. Somewhere on the margins of the system, in a small local radio or in the alternative press, perhaps he will get a job - but his or her impact on the auditorium will be marginalized. Not representing tendentious opinions is punished by the system through exclusion from the system of mainstream media (Chomsky 1987: 125-126).

According to Chomsky, beginning journalists are under illusions of honest news services and spreading the real truth. But shortly after they start working with the editorial staff they are informed by the editor-in-chief that they are too emotional and too involved in specific stories and that they should be more "objective". In other words, the management implies that if they start making troubles they might face obstacles (Chomsky 1992: 68-69). This cover maneuver of the media to maintain an appearance of objectivity and neutrality can be called a pacifying of inconvenient journalists and news-agents.

As we have repeatedly emphasized, Chomsky's "propaganda model" of the media does not presuppose the existence of a literal conspiracy bent on concealment and distortion of the truth. According to him, in the major media self-censorship is applied at the institutional level. The main methods include leaving out facts that embarrass the state ideology and narrowing the range of public debate on the "conceivable" and "moderate" alternatives, altogether supporting the ideology of corporate capitalism (Winston 2004: 97-98). Also it is not true that the news services are manipulated from A to Z. Media outcome is not uniform, but it is pluralistic on the surface. Finally, in order to serve the interests of the powerful the media must present themselves an appropriately modified but essentially realistic picture of the world (Chomsky 1994a: 94).

A semblance of media pluralism which basically offers the same comments with only slight variations carries out an important effect. It preserves the illusion of freedom, neutrality, (and) a multiplicity of views. The covering maneuver in the form of formal pluralism thus fills the void totalitarian media outcomes by a multiplication of media sources. As Marcuse wrote, "the reality of pluralism becomes ideological, deceptive" (Marcuse 1991: 63).

The effect of pluralism is twofold:

a) Plurality of media sources obscures the factual uniformity of media outcomes. It meets its ideological function.

b) Pluralism thus dampens people's interest in finding alternative information and performs its inhibitory function. 
To explain the second effect: Quantitative pluralism of outputs creates a market with information overload that is indigestible by the public. Natural selection in the search for alternative views is defeated by quanta of qualitatively identical information coming from a variety of tendentious sources. Finding an alternative view becomes more like looking for a needle in a haystack, which most individuals do not have the time nor energy for. The number of media outputs either discourages individuals from seeking alternative views, or it can give them a feeling of effect of majority, whereby as most media assesses thing so and so, an objective view lies precisely at the intersection of the produced uniformity.

The inhibitory function of pluralism even further undermines criticisms of Chomsky which was raised in the name of free access to the development and promotion of alternative information on the Internet. As Chomsky points out the Internet is starting to rapidly commercialize (such as radio and television) and the majority of websites which are mainly used for surfing the Internet offer essentially the same content marked by the influence of corporations as television stations and glossy magazines. True, skilled Internet users know that "the truth can still be found out there", it just has to be sought in strange places (Winston 2004: 104-105). But the question remains the same. How many Internet users will have the time and energy to look for alternative views in a flood of tendentious websites?

The last covering maneuver of the system which we will pay attention to is the illusion of democracy in modern societies and in the media sphere. The media will fit into the role of the mirror of the public opinion. They are trying to make an impression that they present the public opinion and they act not only as protectors, but as well as the representatives of democracy. The truth is that democracy itself in the perception of Western societies is built into the plane of manipulation. The system produces a vicious circle which denotes itself as democratic, then it manipulates the public opinion in order to eventually "democratically" claim the public opinion as an expression of democracy and its democratic legitimacy. A key mechanism of this "democratic" carousel is already hidden in the manipulation of public opinion and thought control.

Finally, according to Chomsky, we cannot forget that "the modern institutions of thought control - frankly called propaganda before the word became unfashionable because of totalitarian association - should have originated in the freest societies. Britain pioneered with its Ministry of Information which intended "to direct the thought of most of the world" (Chomsky 2006: 17). In the beginning of the Cold War, the Austrian orthodox liberal Friedrich von Hayek who criticized Bolshevik propaganda noticed that the most effective way to ensure that all efforts achieve social goals, is to 
arrange it in a way that all might believe this objective. Unknowingly, he, however, brought the focus of this fact not to totalitarian regimes, but to the very nature of Western democracy. "Propaganda is to democracy what the bludgeon is to dictatorship," says Chomsky (1999: 1) and several philosophers agree. For example, Foucault, as we mentioned earlier, notes that where medieval feudal monarchy was sufficient to control the bodies of its lieges, there a modern democratic society must also control the minds of its citizens because only this can guarantee the maintenance of existing regimes. Already a classic theorist of democracy, Alexis de Tocqueville warned of a chronic wasting of democratic mechanisms. According to him, democratic "tyranny" leaves free only the bodies of people, while their souls are being attacked. The rulers no longer say: "You must think like I do or die!" Today they say: "You are free not to think like I do; your life, your property, everything shall remain yours, but from this day on you are a stranger among us" (Horkheimer Adorno 1972: 133).

The tyranny of the democratic majority opinion operates in the society more efficiently than totalitarian violence. The totalitarian system of thought control is based on the dissemination of the official doctrine by the state media and intellectuals. Such a doctrine is readily identifiable as pure propaganda and this helps free the mind. As Chomsky says, an individual in a totalitarian society can distinguish what the official propaganda is and what it is not (Chomsky 1992: 62-63). In democracy, however, this difference is eliminated. People are surrounded by propaganda without being aware of it. The doctrine absorbs all their thinking and, unlike totalitarian societies, it leaves space for negation. Dissent under the dominion of democratic illusions becomes redundant. Democracy in this direction, according to Marcuse, is presented as "the most efficient system of dominion" (Marcuse 1991: 63).

According to Chomsky, totalitarian institutions running all the media may even allow the media a much greater scope for certain unconventional thinking and deviance because they pose much less a threat for the totalitarian system. Power of totalitarian systems still relies primarily on violence, while democracy stands or falls on the control of thought (Chomsky 1996: 148). Ultimately, democracy is therefore also as totalitarian as official totalitarian regimes. As Marcuse explains, "totalitarianism" is not just only "a terroristic political coordination of society but also a non-terroristic economic-technical coordination which operates through the manipulation of needs by vested interests. It thus precludes the emergence of an effective opposition against the whole. Not only a specific form of government or party rule makes for totalitarianism but also a specific system of production and distribution which may well be compatible with a 'pluralism' of parties, newspapers..." (Marcuse 1991: 33). 
Chomsky does not see a big chance to break out the totalitarian dominion of media manipulation. He thinks about alternative media that might be actually controlled democratically but he does realize that their position remained logically marginal (Chomsky 1994a: 95). On the other hand, democratic transformation of the mainstream media is almost impossible according to Chomsky: "It's as if we asked whether it is possible to have more democratic corporations. The only way to do this is to get rid of them. (...) You cannot really affect the structure of power. It would really mean a social revolution" (Chomsky 1999: 9). True, Chomsky does not remain completely pessimistic. According to him, it makes sense to move the border of the system as well as to try to influence the mass media policy. As he says: "The mass media institutions are complicated and full of internal contradictions. On the one hand you are trying to indoctrinate and to control and, on the other hand, there is a sense of professional integrity" (ibidem). In connection with Chomsky's optimistic emphasis on human common sense we can speak about a certain chance that the public breaks free from the web of media manipulation (Chomsky 1992: 11-12). It is essential to think critically and to find the energy to explore the truth. Chance is not great, but the attempt to create "a system error"is never futile.

In this respect, several modern social theorists as well as postmodernists agree with Chomsky, including Richard Rorty and Michel Foucault. According to them "a convulsion is needed, so that our imagination and will are so limited by the socialization we have received that we are unable even to propose an alternative to the society we have now" (Rorty 1991: 231-232).

So the question is: how to wake up from the "matrix"? How to find a way out of the web of manipulation and indoctrination which is more perfect, more sophisticated and more elaborate than ever before?

\section{Jamesonian versus Scottian view: Can We Escape?}

In the last chapter I would like to focus on the criticisms of Western society which was offered by the classics of critical theory as Herbert Marcuse and Erich Fromm. They present the modern capitalist society as totalitarian and deeply rigged one. The basic formulas of system ideology preaching the spread of the values of consumerism, individualism and hedonism (Fromm). The economic system obtains the support from population in this way and can reproduce itself.

According to some interpretations, there is no escape from the environment system manipulation (Foucault, Marcuse, Jameson), but there are also some opinions arguing that the system of indoctrination can intervene only in the public, official discourse, but not in culture and behavior patterns of marginalized groups (Scott, Bloch, Williams). I will try to analyze and interpret 
these two intuitive insights systematically. In this context, I will develop the thesis that the value of truth is not as an epistemological or metaphysical regulative, but as a socio-emancipating force that may have a decisive influence in the formulation of alternatives to the current (post) modern globalcapitalist society in the environment of total manipulation .

Nowadays, the basis manipulation system in current capitalist society is that the elites need people who are able to think „technically“. But what is important - people should use the reason only instrumentally, not as a value. They should not think about the essence of problems but only about the technical solution of problems. They should not speculate about the absurdity of the system but only efficiently deal with everyday situations. The highest social objective has become a rationality and empty, meaningless efficiency. People have been transformed into a kind of robots whose primary objective is „to work optimally“, to adapt, to behave according to market forces, flexibly, purposefully and opportunistically. And why? Simply, because the system needs us to be(have) like this. Disciplined masses of consumers whose only one concern is to work efficiently, not to revolt under any circumstances and think about whether they buy a phone from brand X or Y. Do not think, just go shopping. This is what the subject of (postmodern) society should look like. Otherwise, the stability of the system cannot be achieved. The media serve only as useful tools of how to achieve this goal. No wonder that an increasing proportion of free time in the modern era is filled by empty mindless consumerism. As if life was not longer about humans, about relationships, empathy and solidarity. As if it was only about a passive consumerism. This is accompanied with alienation and a loss of interest in other people. A consumerist attitude to life deprives humans of values. They consume products, without needing them. They consume opinions without any evaluation. They consume ideology without searching any values in it. They consume their life, instead of living it.

Foucault describes the process of power influence, respectively manipulation as a system from which it is not possible to escape. According to his opinion, we live in a society of surveillance in which we feel that we are constantly under control. Something like a hidden camera, which accompany us everywhere. And we never know whether it is already on or off. It could well be off all the time but we would have behaved exactly as it is expected of us. Because - what if? We carry an „,inner policeman“ in our heads which is more effective than all the repressive mechanisms of the state. The modern system controlling people is much more effective than the totality ever was. Today it is not only about doing what is expected from you. Today it is important that also you would want to do what is expected from you. Formerly it was enough to control only people's bodies in order to slave to the lords, not 
would to obey physically. They could think whatever they wanted, they had only to obey outwardly. Today it is different. The system went further. Today the thing is to pacify our heads (Foucalt 2000; cf. Buraj 2000).

Propaganda and control is no longer the domain of intelligence services or public policy as it was in the previous regime in the Eastern Europe but it infiltrated also our bedrooms, even our innermost feelings. It is like in the end of the novel 1984 when the hero succumbs to all the torture, pressure and propaganda, and eventually gives up logic and common sense. He even starts to believe that he loves Big Brother. Today the majority of people who express their opinion on social issues are at this stage.

It is getting much harder to escape from the trap of system manipulation. The ideology has hit the whole society and practically swallowed all the space, from which the fundamental ideological system settings can be resisted. While in the past the task of the systematic „diversant" was fulfilled by high culture, art, philosophy etc., it would be immensely hard to trace any kind of critical thinking in these fields today. Jameson points it out when he writes that any kind of autonomy in the cultural field which we know from the past is excluded in today's world. It is impossible to keep distance from the system. It is not that critical speech was banned. The problem is that the system absorbs it. As illustrated by Jameson, today the expression of cultural and political resistance, just as the punk band The Clash in the 70-ties would be impossible, since all attempts of similar expressions of resistance are absorbed by the system. The hidden totalitarian system settings prevent the cultural interprets from taking a critical distance from it.

The new global network which has thus been created tramples down any kind of thinking and everything that seems to be counter-systemic, by disarming and changing it into a commercial phenomenon which is characteristic for the system (Jameson 1991: 48-49). The symbol of the revolution Che Guevara is this way transformed into a spiritless topic on hundreds of thousands of T-shirts all around the world, the radical punk culture is transformed into a conformist fashion accessory, ecological radicalism was absorbed by the system as an advantageous business, utopian visions were exploited in the development of low-cost marketing strategies. The system has absorbed all that once formed counterculture. There is no escape from the system of market values and consumer culture according to Jameson (1991: 206).

The alternative thinking is dangerous for every regime. The difference is that while in the era of the former regime alternative thinking was latently considered to have the status of something decent, although something dangerous and dissident, today critical thinking is degraded to something a priori naive, stupid and crazy. During the former regime everyone knew what 
the regime's propaganda was and every person was capable of differentiating it from the reality. Today we are not capable of this. The manipulation went so far that we are not able to differentiate between the truth and lies, reality or propaganda. And when an alternative idea appears the intellectuals of the regime do not have the role to fight it or argue with it, but to discredit, ignore or ridicule it. It can never get into mainstream media. In case it does appear there it is labelled as a curiosity in order to scare people and prevent them from taking it seriously. It is there only either in connection with something repulsive or ridiculous or in connection with looting anarchists, terrorists or extremists or they allow to interview a slightly drunk illiterate person at a market who is not even capable of forming a sentence, even if what he says is a hundred times more important than the allegations of the intellectuals of the regime, the speakers of banks, well-paid analysts or political scientists. The goal is to create the world without alternatives, the world without thinking.

In one of my books, I named this cobweb as the „matrix of capitalism“. The question is: Is it possible to wake up from the matrix? Is it possible to defeat capitalism? If we have a look at the current situation of the masses of the poor and people becoming poorer, ordinary citizens, the low classes, in short, people who do not own the means of production we can conclude that they can be divided into two categories. The vast majority of these people live in the Third world, i.e. in the frightening conditions of the developing world; they are hungry, poor and undernourished. Many of them are uprooted from their traditional communities, they are forced to give up the farming way of their life which granted them at least partial self-sufficiency and if they want to survive they have to apply for a job at the subcontractors of supranational corporations which have their own brutal factories worldwide (the sweatshops, called „maquiladoras"). These people work like slaves, without social rights, in undignified conditions for absurdly low salaries. Those who are not so „lucky“ to find a job either die of hunger or make a living by prostitution, commiting small crimes or begging. This is the situation in most of the world, excluding Europe, North America, Japan and Australia. In the above-mentioned so-called developed countries of the North, the position of the major part of population is also threatening - in the name of neo-liberal ideology, the model of social state and workers' rights is being gradually degraded, and social vulnerability and inequality is increasing. While in the Third World the situation of the majority of the population is still closer to Marx's revolutionary formulas „they have nothing to lose but their chains", the majority of population in the countries of the OECD resembles a condition of relative deprivation which was described by Alexis de Tocqueville. According to Tocqueville's theory of rising expectations revolutions occur in a society when people's expectations come into a direct conflict with social reality (Krejčí 1992). Nowadays more and 
more European countries implement austerity politics and neoliberal reforms with uncompromising vehemence and this revolutionary contradiction describes this situation in a relatively correct way.

As it seems, the objective conditions for radical change have an increasing presence. While a few decades ago an extensive welfare state functioned in western Europe, there was practically no unemployment or poverty, today the situation is so much more dramatic and people are starting to protest. While a few decades ago the most of the Third World lived a traditional way of life and had no idea there could be better conditions for living, globalization plunges the most of the world's population into the position in which soon they will have nothing to lose but their chains and they will become aware of this. In terms of objective conditions a revolution is about to break out. Therefore, the European capitals are filled by street protesters. Therefore, it has long been boiling in the Third World, particularly in Latin America.

The system has been resisting so far. Thanks to the control over politics, media, science and education, economic and political elites (in the present era of global capitalism, notably the transnational capital and related political parties) are successfully pursuing neoliberal reforms without any compromise which lead to deepened social polarization, but also do manipulate and fool people who instead of following their interests are mistaken under false impression that social vulnerability will bring them more freedom; and that consumer desires define their purpose of life; and that class solidarity is not in their interest and so on. In an environment of absolute hegemony of neoliberal ideology and individualistic values, any intellectual effort to describe alternatives seems as „throwing peas against the wall“. This is the interpretation which I introduced at the beginning of my paper. Foucault talks about the society of surveillance, about biopower from which there is no escape. Jameson highlights that, whereas the post-modern culture is vehement and as it absorbs each alternative, it makes any critical distance virtually impossible. But there are also other authors with similar conclusions: Althusser describes the ways in which ideological state apparatuses comprehensively manipulate people. Fromm and Marcuse underline that market society in the process of indoctrination enters our bedrooms. The common theme is that there is no escape. Simply, there is no way to escape the environment of manipulation.

Against such a view, however, there is an alternative interpretation. Even according to this interpretation people are manipulated, fully indoctrinated and disciplined. But even the environment of ideology, in which the majority of the world's population is, is not without a mote of beauty. The elites possess media, politicians, and experts. In spite of all this, ordinary people are subject to their manipulating schemes only apparently. This fact was pointed out by an 
American author James Scott in his anthropological study „Domination and the Arts of Resistance“. He demonstrated that the oppressed social classes, such as the slaves in slave society, manifested their agreement with the regime and social order only externally. In public, they showed their obedience very ostentatiously, as much as their submissiveness and discipline. This does not mean that they consciously accept and share all the ideological rubbish which the system produces to legitimize injustice and inequality. These people do not share the values of the oppressive system inherently, they only successfully pretend it because they need to stay alive ( survive). At the moment when it is possible to realize their substantial interests and values they reach for their opportunities spontaneously, respectively they stick out from the shell of fictional consent. As one proverb of Jamaican slaves captures it: „Play fool, to catch wise" (Scott 1990: 3).

Snobbish upper classes are eased by the feeling that those at the bottom were pacified. However, when by accident some Mexican profiteer's Audi is damaged in the middle of lower class neighborhood on the outskirts of Mexican Guadalajara, a member of the elite very quickly realizes whether the "scum" indeed shares his value system, or they recognize his status, respect his arrogance, or cherish his property ... Even in the American or European cities there are areas where the legs of the members of the higher or middle class would not enter. In the Third World such slums make up the major part of populated areas. It is vain for the elites to think that they manipulate the majority of the population adequately. Lower classes just pretend their agreement with the regime and with the values that are dictated to them.

As Scott explains: „Every subordinate group creates... 'hidden transcripts“ that represent a critique of power spoken behind the back of the dominant. ... (Therefore) the process of domination generates a hegemonic public conduct and a backstage discourse consisting of what cannot be spoken in the face of power" (Scott 1990: xii). So, if we really want to know what those on the bottom think, it is not enough to analyze the products which are thrown on them. Yes, even in Western societies, the members of the lower classes will play this game which was prepared for them by elites. But what is happening in their inner world, into which the elite have no access, is a different matter. It is likely that the values such as individualism, consumerism and career are not relevant there. The bourgeois values do not prevail there. There we can find rather deep distrust towards higher classes, traditional solidarity schemes of reality, as well as spontaneous resistance to the official authorities. According to Scott these alternative "hidden transcripts" of subordinated classes can be found in gossip, folktales, gestures, jokes, amateur theaters and so on (Scott 1990: xiii). The conclusion is clear. As Noam Chomsky says: „Outside of ideologues, the academy and the press, no one thinks that capitalism is a viable 
system and nobody has thought that for sixty or seventy years -- if ever" (Chomsky 1993a: 9).

The German philosopher Ernst Bloch who influenced Critical theory in many ways pointed this out already during World War II and shortly after. In his famous work „The principle of Hope“, he argues that hope enters everyday consciousness of human beings and their articulation in cultural forms, from fairy tales to major philosophical and political utopias. According to Bloch, the individuals are ,incomplete“ because they are "shaded“ by dreams about a better life and utopian eagerness. As he writes: „As long as man is on a bad way, both private and public existence are pervaded by daydreams; dreams of a better life than that which has so far been given him" (Bloch 1996: 5). In his work, Bloch therefore performed systematic research of ways how dreams, stories, myths, popular culture, literature, theater and all forms of art, as well as political and social utopias, philosophies and religions contain emancipatory moments (Ransdorf 2000: 31).

According to Bloch, the sphere of hope is something which is ignored by contemporary science since it fails to think in categories other than the strictly realistic „happened" and „did not happen“. Media and cultural industry deprive us of what Bloch called the principle of hope (Bloch 1996: 4-7). They enforce on us the idea that no alternative is possible. This is the basic motto that is imperceptibly passed on us in movies, broadcasts or media products. In doing so, the whole human history is full of hope, utopias, dreams, alternatives which have been developed precisely in those times when people have been doing the worst. As Oscar Wilde said, the map of the world which did not show the island of Utopia is not worth glancing at. And this is what Bloch tried to point out: that the alternative is waking up just in time when oppression is the strongest. As he explained, the doctrine of natural rights was born as a utopian demand at a time when the despotic regimes ruled by cruel human rights violations (Bloch 1996: 540).

The value of equality has gained its importance in the fight against inequality and the value of liberty in the fight against oppression. As we can see, the concept of human rights could only arise in the context of arbitrary despotic regimes, merely as a contradiction to a monstrous reality, it would therefore seem that the importance of freedom arises only in the contexts that negate freedom, in the system of oppression which is adequatly visible and complex - oppression that is total. Also, the importance of equality cannot originate in the mind of man without experiencing inequality; brotherhood cannot be named brotherhood without men (and women) distancing themselves from the existing alienation. Progress is meaningless without stagnation; health without disease and good without evil. 
The question then is: can the era of total manipulation and indoctrination about which Jameson, Marcuse and Foucault write, which is unprecedented in all human history, in short, be for the first time in history when the value of truth becomes authentically named, but not as epistemological regulative or metaphysical imperative, but as a pure opposition to manipulation, as a sociopolitical idea, as an emancipatory utopian project that gives power to people to fight against manipulation? Is there a chance that the principle of hope will bring a change that is yet quietly slumbering in the minds of ordinary people and which the eye of any official bodies does not penetrate?

Vaclav Havel once said: that is it extremely short-sighted to believe that the face which the society shows to the current ruling elite is the only real face? That no one can recognise all the potential that is hidden in society? ${ }^{2}$ Could the year 1989 be not the last of its kind? For those who rashly believed in a kind of the end of history it is hard to hear it but history continues and, with it, so does the resistance to lies and injustice.

Michael Walzer mentioned the Velvet Revolution in one of his studies. He writes that in 1989 he saw the television images of people marching through the streets of Prague, in spite of philosophical relativism, epistemological education and postmodern culture he immediately knew what the words "truth“ and ,justice" mean. He knew immediately what banners of the protesters refer to. He realized immediately what purposes those ordinary people had in their minds. The people at the squares of Prague and Bratislava in fact did not demonstrate for any of the epistemological theories of truth, nor for some modern concept of justice. They demonstrated for absolutely „ordinary" truth and ,ordinary“" justice. Simply they no longer wanted to be misled by the party press, they did not want to be manipulated by political leaders. They wanted to end arbitrary arrests, they wanted equal and impartial applications of the law, removing the privileges and prerogatives of party elites - in short, they wanted the end of totality (Walzer 2002: 18-19). If this is the understanding of the value of truth as the „ordinary" truth, as the political and social emancipatory power, then there is a chance that in the environment of the total manipulation there will be just such the value of the truth that will survive even in the toughest oppression in order to be waken up in the right time on the street and start a resistance force.

Or is it otherwise? Has propaganda succeeded to penetrate for the first time in human history into the innermost feelings and patterns of behavior that the lower classes kept intact? Has the system managed to colonize even Scott's „hidden transcripts"? After all, the production of fairy tales has been already monopolized by Hollywood industry! And even the historian Nicholas

${ }^{2}$ Cf. the motto of the book in Scott 1990. 
Abercombie who, like Scott, is of the opinion that the dominant ideology could never penetrate the lower class (the evidence is supported by the cultural separation in the feudal era or specific culture of working class in the past two centuries) admits that the means of transmitting information are so technically advanced in the era of the late capitalism that for the first time in history it is possible to hit the lower classes by a dominant ideology of the system, whether through media manipulation or through a system of compulsory education (Lukes 2005: 161).

Selected facts support this: we live in the post-soviet era when for the first time in human history people are afraid to transcend the reality, when utopia is not only ironized, but practically hated. The media teach us to think within onedimensional realism and pragmatism: we should not indulge in the hope and to deal with utopian "babbling" about change that can never come about. We should deal with ourselves, with careers and technical facilities that we can make use of in order to achieve our career goals. Utopia is not only impractical, but even demonic because it inevitably leads to its contrary - it is simply a prelude to the Gulag. Therefore let us stop dreaming - that's the motto the media indoctrinated into our heads by almost every broadcast. Maybe the classic fairy tale movie called The Neverending Story (Wolfgang Petersen, 1984) tried to warn us against this indoctrination. In this neverending story the fantasy empire gets itself into danger because people stop dreaming, stop looking beyond the horizon and stop hoping.

According to the interpretation which we might call ,jamesonian“, (post)modern culture managed to colonize the whole world of fantasy, the world of alternatives, the world of hope. Media and cultural manipulation is according to this interpretation total, complex and comprehensive. From such indoctrination there is no escape. According to the second interpretation, let's call it Scott's, indoctrination refers to the only official story, only the public discourse, only to such an extent that the regime institutions are able to recognize and detect it. However, behind the scenes an entirely different story is taking place - the story of resistance, the story of hope, the story of alternative values. This interpretation gives hope for a change, we need only to wait when the sleeping giant gets awaken. In Bloch's words: whether it will be the pursuit of happiness, freedom, brotherhood, golden age, Utopia, God's judgment day or the country of milk and honey, human dreams and desires will always be here and with them there will always remain the hope for a change (Bloch 1996: 1374-1375).

Here lies the huge progressive potential of liberal Marxism, left-wing communitarianism, critical theory, radical Rawlsianism or other forms of progressive thinking that critically mirror the current system and try to offer anti-capitalist alternatives. Their methods are various but together they pursue 
the values of empowerment, emancipation, social justice and genuine equality among people. Together they offer a hope that is desperately needed in this hopeless era.

\section{REFERENCES}

BLOCH, E.: The Principle of Hope. Volume One I., II. III. Cambridge, Masssachusetts: The MIT Press, 1996. 1420 p. ISBN 0262521997.

BURAJ, I.: Foucault a moc. Bratislava: Univerzita Komenského, 2000. 185 p. ISBN 8022314765.

CHOMSKY, N.: On Power and Ideology. The Managua Lectures. Boston, Masssachusetts: South End Press, 1987. 140 p. ISBN 0896082903.

CHOMSKY, N.: The Culture of Terorism. Boston, Masssachusetts: Black Rose Books Ltd., 1988. 269 p. ISBN 0921689284.

CHOMSKY, N.: Chronicles of Dissent. Interviews with David Barsamian. Monroe, Maine Common Courage Press, 1992. 210 p. ISBN 1873176856.

CHOMSKY, N.: The Prosperous Few and the Restless Many. Berkeley, California: Odonian Press, 1993a. 95 p. ISBN 1878825038.

CHOMSKY, N.: Rethinking Camelot. JFK, the Vietnam War, and U.S. Political Culture. Boston: South End Press, 1993b. 172 p. ISBN 0896084582.

CHOMSKY, N.: Letters from Lexington. Reflections on Propaganda. Monroe, Maine: Common Courage Press, 1993c. 160 p. ISBN 1873176066.

CHOMSKY, N.: What Uncle Sam Really Wants. Berkeley, California: Odonian Press, 1994a. 111 p. ISBN 1878825011.

CHOMSKY, N.: Keeping the Rabble in Line. Interviews with David Barsamian. Monroe, Maine: Common Courage Press, 1994b. 319 p. ISBN 1567510337.

CHOMSKY, N.: Class Warfare. London: Pluto Press, 1996. 185 p. ISBN 1567510922.

CHOMSKY, N.: Nevyhnutné ilúzie, média a propaganda. Bratislava: Nakladatel'stvo Bod zlomu, 1999. $12 \mathrm{p}$.

CHOMSKY, N.: Pohl'ady zvnútra II. Bratislava: KUBKO GORAL, 2001. 71 p. ISBN 9788088858409 .

CHOMSKY, N.: Hegemonie nebo přežití. Americké tažení za globální nadvládu. Praha: Mladá fronta, 2006. 352 p. ISBN 8020413510.

FOUCALT, M.: Dozerat' a trestat'. Zrod väzenia. Kalligram, Bratislava 2000. 321 p. ISBN 8071496634.

GÁL, E. - MARCELLI, M.: Za zrkadlom moderny. Bratislava: ARCHA, 1991. 320 p. ISBN 8071150258.

HORKHEIMER, M. - ADORNO, T. W.: Dialectic of Enlightenment. New York: Continuum, 1972. 304 p. ISBN 0804736332.

JAMESON, F.: Postmodernism, or the Cultural Logic of Late Capitalism. Durham: Duke University Press, 1991. 438 p. ISBN 0822310902.

KREJČÍ, J.: Dějiny a revoluce. Praha: Naše vojsko, 1992. 223 p. ISBN 8020601686.

LUKES, S.: Power: A Radical View. London: Palgrave Macmillan, 2005. 192 p. ISBN 0333420918. 
MARCUSE, H.: Jednorozměrný člověk. Praha: Naše vojsko, 1991. 192 s. ISBN 020600752.

MILLER, R. W.: Analyzing Marx. New Jersey: Princeton University Press, 1984. 319 p. ISBN 0691014132.

RANSDORF, M.: Rozumět Rusku, rozumět Leninovi. In LENIN, V. I.: Stát a revoluce. Praha: Otakar II., 2000. 191 p. ISBN 8086355802.

SCOTT, J. C.: Domination and the Arts of Resistance. Hidden Transcripts. New Haven \& London: Yale University Press, 1990. 251 p. ISBN 0300056699.

SVENSSON, P.: Teorie demokracie. Brno: Centrum pro studium demokracie a kultury, 1995. 287 p. ISBN 808595902X.

WALZER, M.: Hrubý a tenký. O tolerancii. Bratislava: Kalligram, 2002. 240 p. ISBN 8071494402.

WINSTON, M.: Chomsky. Bratislava: PT, 2004. 120 p. ISBN 8088912539.

Luboš Blaha (born 1979) is a Slovak philosopher, political scientist and politician. Currently he is a Member of Parliament and the Chairman of the Committee of National Council of the Slovak Republic on European Affairs (since 2012). In 1998 - 2003 he studied at The Faculty of Political Sciences and International Relations, University of Matej Bel, Banská Bytsrica, the subject: political theory. In 1999 2004 he studied at The Philosophical Faculty of Comenius University, Bratislava, the subject: philosophy. In 2004 - 2007 he was the PhD. student at the Insitute of Political Sciences of Slovak Academy of Sciences. Since 2007 he has been the employee of the Department of Political Sciences of SAS. The degrees: $2003-$ Mgr. (political science), 2004 - Mgr. (philosophy), 2004 - PhDr. (political science), $2008-P h D$. (political science). His scientific work is aimed on the political philosophy, especially the analysis of social justice. As regards the political theory, he mainly concerns the analysis of Liberalism, Communitarianism and Neo-Marxism, concretely the philosophical theories of John Rawls, Robert Nozick and Michael Walzer. In the field od Neo-Marxism he concerns especially the American and British authors of Analytical Marxism (John Roemer, G.A. 
Cohen, Rodney Peffer etc.). He is the author of five monographs: Social Justice and Identity (2006), Back To Marx? (2009), Paradoxes of Prosperity (2010), Paradoxes of Progress (2010) and Matrix of Capitalism: Is the Revolution Coming? (2011), as well as various scientific studies on political-philosophical issues (the theories of justice, the welfare state, media manipulation, political Left etc.). He works as a political scientist at Slovak Academy of Sciences and teaches at Faculty of Social Science of Univerzity of Ss. Cyril and Methodius in Trnava.

PhDr. Luboš Blaha, PhD.

Katedra politológie a európskych štúdií

Fakulta sociálnych vied

Univerzita sv. Cyrila a Metoda v Trnave

Bučianska 4/A

91701 Trnava

Slovenská republika

E-mail: lubos.blaha@gmail.com 